\title{
Hand perforation caused by a Gafftopsail catfish (bagre marinus) in a fisherman from Northeastern Brazil
}

\section{Perfuração da mão por bagre branco (bagre marinus) em pescador do nordeste do Brasil}

\author{
Luís Arthur Brasil Gadelha Farias ${ }^{1}$ (D), Rodrigo Pinto Lourenço ${ }^{1}$ (D), Roberto da Justa Pires Neto $^{2}$ (i)
}

1. Departamento de Saúde Comunitária, Faculdade de Medicina, Universidade Federal do Ceará, Fortaleza, Ceará, Brasil. 2. Programa de Pós-graduação em Saúde Coletiva, Universidade Federal do Ceará (UFC), Fortaleza, Ceará, Brasil.

\begin{abstract}
A 39-year-old male fisherman from Ceará State in Northeastern Brazil presented to the emergency room complaining of intense pain, edema, and bleeding in his left hand (Figure 1A-1B), He had a recent history of traumatism with hand perforation caused by the stinger of a gafftopsail catfish (Bagre marinus) (Figure 2A-2C). The injury occurred 4 hours prior when pulling his fishnet in the ocean. Right after the injury, the patient presented local pain and classified as eight in a visual analogue scale of pain. He denied systemic symptoms such as fever. On physical examination, he presented with two perforations separated by about $2 \mathrm{~cm}$ with slight bleeding (Figure 1A), local edema, and pain in his left hand (Figure 1B). Local cleansing of the lesion was performed. He was advised to apply warm compresses and used analgesics/anti-inflammatory drugs with the improvement of the inflammation. Systemic antibiotics were not necessary.
\end{abstract}

Keywords: Occupational accidents. Fishermen. Catfish. Venomous fish.

\section{Resumo}

Um pescador de 39 anos, natural do Ceará, na região Nordeste do Brasil, deu entrada na emergência com queixa de dor intensa, edema e sangramento no dorso da mão esquerda (figura 1A-1B). Ele apresentava história recente de trauma na mão por ferrão de bagre branco (bagre marinus). A lesão ocorreu durante $o$ ato de puxar a rede do oceano, quatro horas antes do atendimento. Logo após a lesão, apresentou dor intensa, nota 8 na escala visual analógica de dor. Ele negou sintomas sistêmicos, como febre. No exame físico, apresentava duas perfurações separadas por cerca de $2 \mathrm{~cm}$ com leve sangramento (figura 1A), edema e dor na mão esquerda (figura 1B). Foi realizada limpeza da lesão. Alem disso, foi orientado a aplicar compressas mornas e fazer uso de analgésicos /anti-inflamatórios para a melhora da inflamação. Antibióticos sistêmicos não foram necessários.

Palavras-chave: Acidentes de trabalho. Pescadores. Peixe-gato. Peixe venenoso.

Figure 1. A. Perforated lesion caused by the stinger. B. Remarkable edema of his left hand.

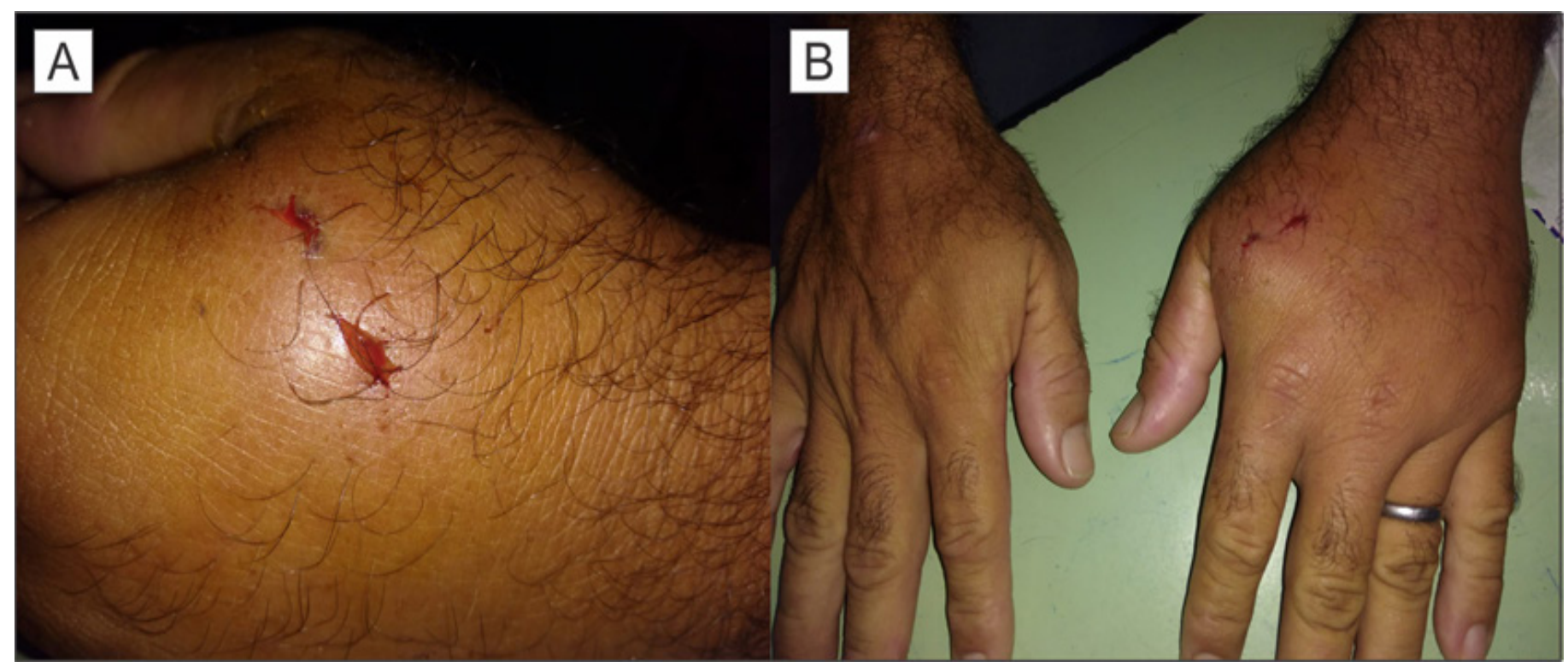

Correspondence: Luis Arthur Brasil Gadelha Farias. Address: Juazeiro do Norte St, number 333, Ed. Rui Castelo Branco, aptoo 102, Meireles, CEP: 60165110. Fortaleza, Ceará, Brasil. Email: luisarthurbrasilk@hotmail.com

Conflict of interest: The authors declare that there are no conflicts of interest, according to the attached document

Recived: 2019 May 2; Revised 2019 Dec 10; Accepted: 2020 Jul 9 
Figure 2. A and B. Bagre marinus, also known as the bagre branco or gafftopsail catfish. Detail: stingers were removed. C. Schematic diagram showing dorsal and pectoral stingers (Elaborated by the authors). Photos: Farias, LABG.

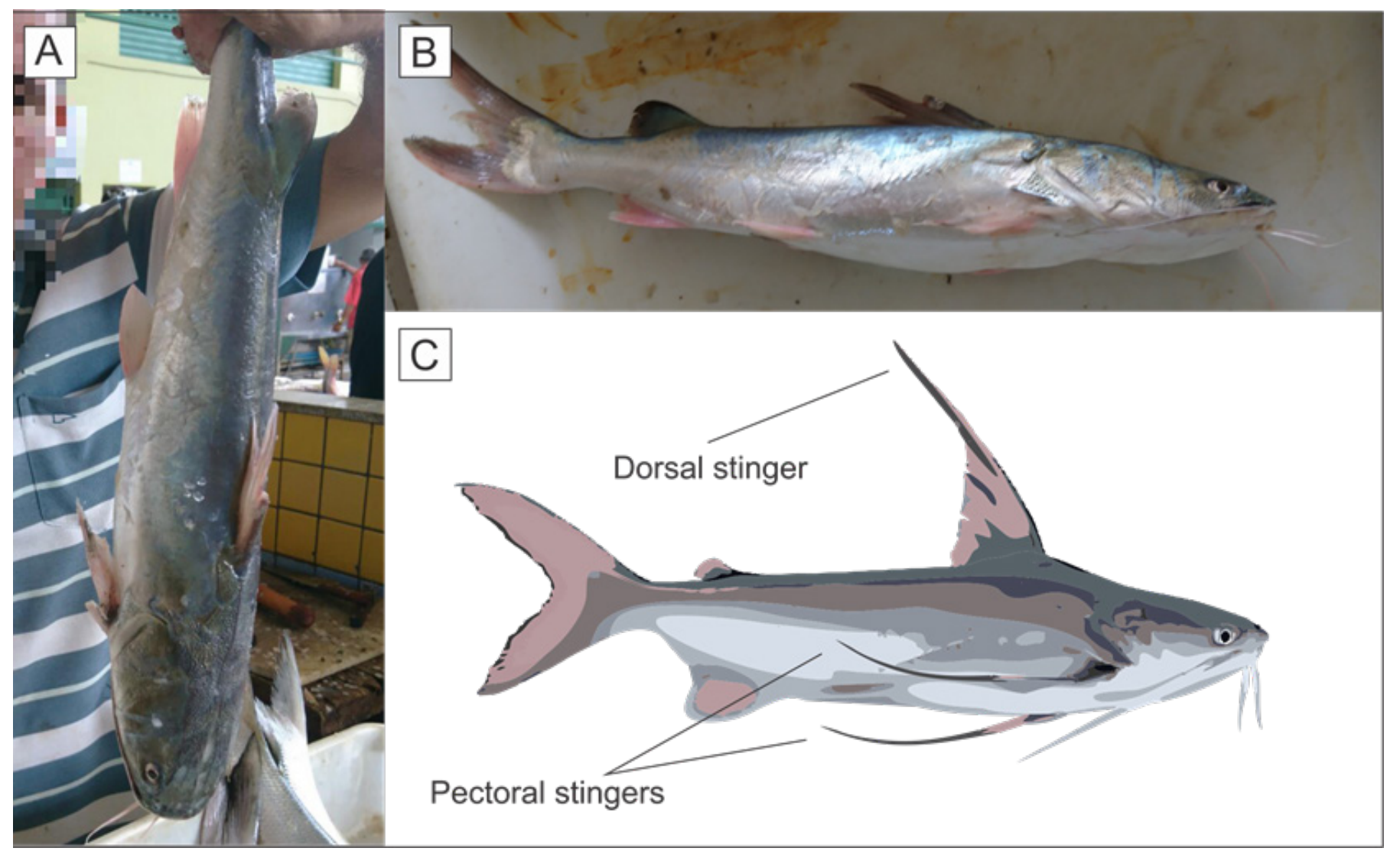

\section{REFERENCES}

1. 1. Eckziegel GC, Dourado FS, Garrone D Neto, Haddad V Júnior. Injuries caused by aquatic animals in Brazil: an analysis of the data present in the information system for notifiable diseases. Rev Soc Bras Med Trop. 2015 Jul-Ago; 48(4): 4607.

2. Haddad V Júnior. Injuries caused by fish in a community of Pantanal fishermen: detection, treatment, and prevention of envenomations and trauma. Rev Soc
Bras Med Trop. 2018 Set-Out; 51(5):700-4.

3. Silva GC, Sabino J, Alho CJR, Nunes VLB, Haddad V Júnior. Injuries and envenoming by aquatic animals in fishermen of Coxim and Corumbá municipalities, State of Mato Grosso do Sul, Brazil: identification of the causative agents, clinical aspects and first aid measures. Rev Soc Bras Med Trop. 2010 SetOut; 43(5):486-90.

\section{Como citar este artigo/How to cite this article:}

Farias LABG, Lourenço RP, Pires RJ Neto. Hand perforation caused by a Gafftopsail catfish (bagre marinus) in a fisherman from Northeastern Brazil. J Health Biol Sci. 2020 J; 8(1):1-2. 